\title{
Genetic Templates and Coded Worlds: David Hontiveros' Seroks Iteration 1: Mirror Man as World-Driven Dystopia
}

\author{
Sydney Paige Guerrero
}

University of the Philippines-Diliman, Quezon City, the Philippines

\begin{abstract}
In 2012, David Hontiveros revisited and expanded the world of his Carlos Palanca Memorial Award-winning short story, "Kaming Mga Seroks", in Seroks Iteration 1: Mirror Man, which is set in a dystopic future where cloning is a booming industry, and genetic templates are pirated to create seroks or clones of clones. Mirror Man employs a fragmented style of story telling that crafts a long-form narrative that is neither plot nor character-driven but world-driven. Through a mix of interviews, messages, recordings, and more, Mirror Man delves deeper into the world's history and current events than it does into the lives of its recurring characters. In this way, the world of Seroks is not so much a backdrop against which the story takes place but the story's main draw as it utilizes its dystopic setting to critique Philippine society, thus prompting the reader to reconsider the trajectory of the Philippines and reimagine its future.
\end{abstract}

Keywords: Asian worldbuilding, Philippine science fiction, dystopian literature, Philippine literature in English

Character, plot, and setting are commonly described as "ingredients" of fiction — better understood not as separate and independent elements but as overlapping dimensions that influence each other and together form a story. A writer often chooses, consciously or unconsciously, to give one dimension primacy over the others, leaning on a particular dimension to serve as the engine that drives the story forward.

For most stories, the dimension in question is usually considered to be either character or plot, with character-driven stories focusing more on internal conflict and plot-driven stories focusing more on external conflict. According to speculative fiction writer Lisa Tuttle, genre fiction is usually plot-driven (19), but perhaps this either-or way of understanding what drives a story is reductive for speculative fiction, a genre that is usually boundless with its possibilities.

Categorizing stories as being plot-driven or character-driven perhaps makes more sense for realist stories where the setting is assumed to be the real world, but speculative fiction, by its very nature, cannot make such an assumption. This is not to say that realist settings do not influence character and plot - they do - but that the 
internal logic of realist settings necessarily follow known systems and laws of physics, and therefore rely on worldbuilding to a lesser extent than speculative fiction. Science fiction and fantasy, in particular, rely on worldbuilding that "[evokes] a world that is plausibly, vividly different from ours" (Kilian 139), worlds that are "structurally different from the real one" in terms of both the cosmological struc ture and social structure (Eco qtd. in Bertetti 50). In this way, in speculative fiction, "[the] places and spaces in which story occurs are not inert or merely backdrops to action [...] worldbuilding is not just about creating colorful stages for your characters worldbuilding can be part of what is taking place" (VanderMeer 241), and "the world itself can be the reason for the audience's attention and time" (Wolf 72).

So, perhaps speculative fiction offers another way of understanding story engines — not just character or plot-driven but world-driven. Guidebooks and histories of fictional worlds do not fall under the scope of worlddriven stories because they are not, in themselves, stories, but are textbook-like reference materials. Instead, world-driven stories must contain elements of plot and character, with the world of a story serving as the primary vehicle for narrative and theme. World-driven stories pay special attention to how a world works and how the world came to be. The focus of world-driven stories is not necessarily how its characters will ultimately impact that world but on how that world has impacted the lives of its characters.

This is the approach that Philippine speculative fiction writer David Hontiveros takes with Seroks Iteration 1: Mirror Man, which was released in 2012. In Mirror Man, Hontiveros revisits and expands the world of his 2002 Carlos Palanca Memorial Award-winning short story, "Kaming Mga Seroks” (trans. "We the Seroks"), which is set in a dystopic future where cloning is a booming industry, and genetic templates are pirated and modified to create seroks or clones of clones.

Mirror Man is one of the few examples of a contemporary long-form Philippine science fiction narrative that is not a graphic novel or komiks. Though the Philippines is currently in the golden age of Philippine science fiction (Ocampo), Philippine science fiction writers still seem to gravitate towards short stories rather than novels, with most contemporary novels focusing on historical fiction (Hidalgo 334). This is perhaps a lingering effect of the desire that started sometime in 1935 to "write novels which were going to be not just novels but the great Filipino novel" (Arcellana qtd. in Jurilla 11), which likely stemmed as much from the concept of the Great American Novel as it did from the legacy of José Rizal (Jurilla 11).

In Mirror Man, Hontiveros does not quite write a novel nor a short story collection and instead merges the short and long fiction forms by creating a tightly woven collection of short fiction that can only be fully 
understood and appreciated when read as a whole, while simultaneously resisting any attempt to condense the narrative into a single summary with the collection's "mosaic" style of storytelling (Wright). Through a mix of interviews, messages, articles, and brief narration from the points of view of the collection's side characters, Mirror Man is an exploration of the world's history and current events, with its characters serving as viewpoints through which the world can be understood rather than fully fleshed-out people with individual arcs. The microplots they each experience feed into a larger narrative of reconstructing the world's history as its dystopic Philippines teeters towards a potentially even bleaker future.

The collection opens with "Kaming Mga Seroks", the piece that inspired the rest of the collection, which is mostly told in the form of a message written by a seroks known as Pequé (a play on the Filipino word peke, which means "fake"). Though Pequé is a seroks of an Oscar model designed to work in the entertainment industry in New Hollywoodland, he lives in a nicho or a tiny cubicle described by Westerners as a "coffin hotel" (Hontiveros 8) and works as a garbageman. Through his message, he tries to get the reader to understand the severity of his situation. He explains that the legalization of cloning and, later, the booming cloning industry began as the result of jihad against the United States, which ended with the release of Iblis, a virus that caused a plague that ravaged the United States. Devasted by the virus, a post-Iblis America was then "assisted" by Japan with economic packages that ultimately led to the entire United States, except for nine states, becoming known as NeoNippon. The virus also rendered nine out of ten male survivors sterile. Pequé explains:

In the bleak aftermath of Iblis, the moral and ethical concerns stunting the development of genetic engineering were conveniently forgotten and the advent of cloning quickly came to pass.

Clones were used for any number of reasons. Foremost among these: as changelings or made-to-order children adopted by the moneyed, yet childless. Almost overnight, cloning became big business worldwide. (6)

As with most technological innovations, the genetic templates used to make the clones were quickly pirated to create clones of clones, known as dupes in the West and seroks in the Philippines, which is likely based on the local slang term for a photocopied piece of paper that was derived from the photocopier brand Xerox. These pirated clones are also modified in terms of skin color, personality quirks, and preferences that would help the pirated clones adjust to whatever purpose they are being created for and whatever country they are being sold to. 
In the case of seroks, they are used as workers that fill the gap created by the collapse of the Philippine middle class. After the Filipino elite consolidated their wealth and formed the megacorporation MaharlikaCo, the middle class "succumbed to the black hole of poverty [...] incapable of keeping pace with rising costs and fixed salaries" (7). As the urban poor community grew, so did the issue of squatting. Communities became overcrowded and suffered from poor sanitation.

Multitudes died ill, homeless, and starving, while the government watched and wrung its hands. It reclaimed vast tracts of land after clearing away all the rat-infested shanties filled with bloated, rotting — and partially consumed — bodies. In the end, the country's economic pyramid was brutally truncated, reduced to its apex of fortunates.

But if there's one thing history has proven, it's that the rich always need other hands to get dirty. Thus, the void in the population was filled (as it was in America) with clones. Or, in our case, with clones of clones. (8)

Though the seroks are poorer than the natural-born lower class, seroks with jobs like Pequé are still considered to be in a relatively comfortable position when compared to seroks engineered for sex work known as seroks putas (trans. seroks prostitutes), who are treated as "expendable sex toys" (9), or seroks that are unintentionally created with defects that either become "chop-chops" (9), a source for organs and body parts, or are sent to "brothels and clubs [...] that cater to a very specific clientele. There [they] roam the rooms and halls, hobbling, shambling, or simply crawling, drooling from harelips, hair falling out in clumps" (10).

Though Pequé has learned how to survive in this world, he is fearful of China's intention to annex the Philippines. Despite China serving as the primary engineers of seroks, China loathes seroks and employs an antipiracy police unit called the Yìhé Quán, also known as Boxers, who execute any dupes found on Chinese soil. Pequé is doubtful of the proclamations that there will be no mass executions in the Philippines and that the seroks population would instead be displaced and re-conditioned if the country is annexed to China. It would be quicker and cheaper to create new dupes than it would be to re-condition the seroks, and, already, seroks are disappearing. Pequé, terrified for his life, pleads with whoever receives his message to help him survive by escaping the Philippines. The message ends, and the story shifts to Hu Han-Min, a member of the Yìhé Quán, evaluating whether his crafted message sounds believable. The story ends with the revelation that Pequé has already been killed, and his memories were extracted and used as the basis for a message meant to lure seroks sympathizers out of hiding. 
The advent of cloning in this story is particularly interesting primarily for two reasons. The first is that despite borrowing from the Anglophone science fiction mega-texts, Hontiveros not only immediately removes the United States as a primary player in this dystopic world, which destabilizes mainstream media portrayals of the United States at the center of science fiction stories, but he negates its existence entirely. The United States, and the West in general, is a minimal presence in the story, with NeuDeutchland (formerly Germany) being the most prominent figure. Hontiveros further subverts mainstream Anglophone science fiction storytelling by deviating from the three-act structure in his collection, which Philippine speculative fiction writer Vida Cruz identifies as a traditionally Western story structure. Cruz says that the three-act structure focuses on conflict, which may be linked to the West's history with colonization, whereas non-Western stories tend to focus on survival, which is something that can also be observed with Pequé and the later stories in the collection.

That centrality of conflict in Anglophone stories may also be particularly evident in science fiction, which is typically rooted in American sensibilities such as "frontier mentality, self-improvement, efficiency through technology, capitalism, independence, and equality", and thus focuses on confrontation and conquest (Cimafranca). These American sensibilities, which are more outward-looking, are in contrast to Filipino values, which are more inward-looking (Cimafranca). As a result of this contrast, when "Philippine sf borrows certain iconography and images from Anglophone sf mega-texts, they seem to [be] re-deployed in different ways across these texts, rendering them as carriers of alternate meanings" (Lee 134). So, if in the Anglophone science fiction mega-text, the rise of cloning is usually associated with military application or intelligence gathering, this is reimagined in Hontiveros's work, with the rise of cloning depicted not as the result of some desire for domination but instead, as Pequé explains, a way to provide children for the "moneyed, yet childless" and barren (Hontiveros 6). In other words, cloning began as a means of fostering family, which is a core Filipino value that affects the portrayal of the most prominent seroks in later stories and is a recurring theme in Philippine literary work across a multitude of genres. Though the Philippines is not a global power or a technological hub in Hontiveros' imagined world, the inception of this imagined world is deeply rooted in Filipino sensibilities, which "Kaming Mga Seroks" establishes from the very first page of the story.

"Kaming Mga Seroks” is also remarkably simple in terms of plot — a plot that only fully takes shape in the last 500 words of the story. Its characters, Pequé and Hu Han-Min, are characters the reader never truly gets to know. Beyond Hu Han-Min's status as a member of the Yìhé Quán, he appears only long enough to deliver that final twist, and Pequé, who the reader knows only for his love of Philippine cinema, his occupation as a garbageman, and his desperation to survive, had never really technically been a presence in the story to begin 
with. Instead, what draws the reader's attention is the way Pequé talks about his dystopia and how the world fell apart.

Dystopias such as Hontiveros' world are usually "worse world[s] extrapolated from consequences of the poor choices being made in the author's time" (Sands 177) with imagined histories that serve as "warning cries: continue on this path or make these choices and here are the horrible alternatives" (180). In the case of "Kaming Mga Seroks, ”Hontiveros examines a future Philippines where the wealth disparity is taken to the extreme. The Filipino elite or the MaharlikaCo, as they are now collectively known, possess not only complete economic control but complete political control as well after usurping the Philippine government soon after the release of Iblis, which is later revealed in the eighth story of the collection entitled "Mystery". Millions of Filipinos suffer and perish under the rule of the MaharlikaCo, and the seroks population is treated as little more than a dispensable tool.

As with most dystopias, Hontiveros' dystopia is steeped with political commentary, and the use of the term "Maharlika", commonly understood as nobleman, is also almost certainly a reference to the propaganda of the Marcos administration. Throughout his political tenure, former dictator Ferdinand Marcos maintained that he once led a guerilla resistance unit against the Japanese during World War II (Novio). The unit, according to Marcos, was called Ang Mga Maharlika, and a 1970 film entitled Maharlika was based on Marcos' alleged heroism (Novio). Marcos' claims were later debunked, and "repeated Army investigations found no foundation for Mr. Marcos’s claims” (Gerth). “During his presidency, Marcos also conferred the name Maharlika on a hall in [Malacañang] Palace and a government-owned broadcast network. The Pan-Philippine Highway is also called Maharlika Highway" (Novio). In the final years of Marcos' Martial Law, Imelda Marcos went as far as having a song commissioned that boasted in its lyrics, "Ako ay Pilipino / ang dugo'y Maharlika" (trans. I am a Filipino, the blood of the Maharlika) (Novio). "Marcos was obsessed with Maharlika" (Novio), weaving this illusion of nobility, of supremacy, so deeply into the fabric of his political narrative that the word maharlika is almost inseparable from Marcos himself. This idea of nobility continues or is at least reimagined in Mirror Man, with a megacorporation in place of a kingdom that rules over what is left of the Filipino people, their reign rife with the same corruption and human rights violations that also characterized the Marcos administration.

Within the context of Mirror Man, these violations are revealed through the news report that a journalist is preparing in the story "Mystery". The report says that approximately three days after the release of Iblis, 
[Several] million people living throughout the Mindanao group of islands simply disappeared.

The missing were comprised almost exclusively of Mindanao's Muslim populace, who apparently abandoned all their worldly possession, and simply vanished. When concerned relatives and friends from other parts of the Philippines realized that they could not get in touch with their acquaintances in Mindanao, the initial thought was, perhaps, Iblis had found its way there...

But what they found here in parts of Mindanao was, arguably, even more sinister.

There were no dead bodies in houses and on the streets. There were no bodies at all...

While everyone was looking in horror to the United States as a bio-weapon of the most insidious and cruel nature depleted their population mercilessly, nearly 7 million people living in the Mindanao group of islands disappeared without a trace. None of them, not a man, woman, or child, has been seen since. (Hontiveros 80-81)

The disappearances in Hontiveros' work bear echoes of the nearly 2,000 real-life documented cases of forced disappearances or desaparecidos during the Martial Law period (Medina), over half of which also took place in Mindanao (Abinales). Similar to the real-life desaparecidos, the exact circumstances of the disappearances in Hontiveros' work are unclear, as is the exact cause of the "apocalyptic mania" (83) that possessed people worldwide, thus causing them to "demanded release in mayhem and violence" (83). The latter was speculated to be the result of another bio-weapon that "caused those infected by it to spontaneously erupt in irrational rage" (83). With the government unable to handle the crises, corporations stepped in to restore order. In the Philippines, “the MaharlikaCo’s Board of Directors, their families, everyone deemed vital to the M-Co cause, was relocated to the now largely vacant Mindanao region. From here, the megacorp worked to gradually restore peace and order to the country" (83), and this megacorporation takeover was mirrored across the world.

As the news report points out, the "only real winners, at the end of it all, were the corporations" (84), and given Hontiveros' clear allusions to the Marcos regime, it is apparent that the chaos from which the Philippines needed saving was very much orchestrated by the same megacorporation who took on the role of the country's savior. Similar to the way Marcos staged attacks from the New People's Army (NPA), exaggerated the threat they posed (Jalkebro) and staged an assassination attempt on Juan Ponce Enrile to justif y the implementation of Martial 
Law (Punongbayan), the MaharlikaCo created the circumstances that led to their complete economic and political control of the Philippines.

At the end of "Mystery", the story adopts a found footage approach, and as the journalist reviews her news report, she plays a recently uncovered video that provides some insight into the Mindanao disappearances. In the video, an American soldier confesses that his team was mobilized a mere 48 hours after the initial outbreak of Iblis to gas an area strongly implied to be Mindanao. According to the unnamed soldier, his team was told that they were following the perpetrators behind the Iblis outbreak and that they were to release a "top secret experimental gas in the area" (Hontiveros 85), using the Iblis outbreak as a distraction that allowed them to leave the area before anyone discovered what they had done. The soldier tearfully insists that he does not know what happened after they released the gas and guiltily wonders aloud at what became of the women and children in the area before he commits suicide.

Through the soldier's video, it becomes clear that the circumstances that led to this dystopic future are not isolated events but premeditated strategies to shift the global power dynamics. The gassing of Mindanao took place too quickly, too efficiently, after the initial Iblis outbreak, and the forced disappearance that left Mindanao deserted provided a convenient location for the MaharlikaCo to consolidate their strength and numbers. Even the Iblis outbreak itself, supposedly perpetrated by Muslims, and the rise of cloning that came from the desire to foster families inevitably translated to business. Businesses, megacorporations, are ultimately the ones who came out on top in the wake of this orchestrated tragedy.

As the journalist prepares her report, separated from her family and alone in the Philippines, the reader can infer that she understands what is at stake - the threat to her safety as a journalist in a country with a history of silencing the media (Elemia) and the importance of holding the perpetrators of such atrocities accountable for their actions, perpetrators who, like many of those responsible for the horrors committed under the Marcos regime, are yet to face justice (Gavilan). Though no one from the MaharlikaComakes a direct appearancein the collection, except perhaps for the stranger who arrives in the Philippines for the first time in “Balikbayan ”, MaharlikaCo's presence looms large in the background of "Mystery."

The same can be said of the fourth story in the collection, "Alipin "(trans. "Slave"). In "Alipin ", the reader meets Aurelio, a sarariman "indentured to one of MaharlikaCo's countless subsidiaries" (54). Hontiveros' description of Aurelio deliberately uses the phrase "indentured to" rather than "works for", implying a sense of servitude that is consistent with the title "Alipin." This implication of ownership over the worker is further 
confirmed in the collection's fifth story, "MRT, Then", where Aurelio is observed by another side chara cter named Dolores. In “MRT, Then”, Dolores notes that “[Aurelio] stands there, looking like he's been shrinkwrapped into the conservative grey suit of a corporate wageslave, the M-Co logo laser-etched at the base of his bald head" (63).

Though iron is swapped for a high-tech laser, Aurelio has been branded by the MaharlikaCo like an object, a piece of property. Aurelio is also a slave to the sprawling business of the entertainment industry, "pissing away what's left of his creditline (with payday a full week away and the rent due before that) on simming time as websoap hunk Benson Beauvoir" (54). Simming (from the word "simulation") is Aurelio's escape from the despair he feels over a lost flashstick and from the typhoon raging outside. Simming allows Au relio to literally experience someone else's life, to see and hear and taste and feel what, in this case, web soap opera actor, Benson Beauvoir, experiences. In the process, he neglects his personal hygiene and remains ignorant of the long-term effects of sim abuse. In many ways, Aurelio has been dehumanized by the world he lives in, lacking any real individual thought, goals, or ambition as he is caught between two industries that he relies on to survive - the MaharlikaCo to meet his basic needs and the entertainment industry to alleviate the mental and emotional strain of surviving in this world. His is not a story of conquering his obstacles but of surviving them.

And this idea of what it means to survive in this world is continued and made more apparent in the story "Sapa" (trans. "Creek"). The typhoon that has been brewing in the background of several of the collection's stories such as "The Twelfth Hour", "Alipin" and "MRT, Then" is at the forefront of "Sapa ". Typhoon Dagundong is every bit as devastating as the real-life typhoons that sweep the Philippines and leave destruction in their wake. In "Sapa”, a group of 'Netheads crowd under a rusted bridge as Typhoon Dagundong rages. Within sight is "the stately and elevated bulk of a corporate subdivision: Oro Hills, a gated, exclusive community for Banco Maharlika employees" (112), which is a detail that once again highlights the economic disparity in this dystopic Philippines and how radically different modes of survival can be a result of that economic disparity.

In "Sapa", 'Netheads are depicted as addicts, not entirely unlike Aurelio, who have had cheap, pirated neural implants installed in their brains that allow them to "stay plugged into the "net, 24/7, their eyes focused on sights once limited to computer screens but now superimposed on their own vision, or in some cases, actually superseding it [...]The worst cases would inevitably wind up getting lost in the glowing, luminous labyrinth of the web" (113). The "Netheads huddling under the rusted bridge are drawn to the unsecured wi-fi channel of a nearby establishment, too poor to support themselves as their addiction to the "net consumes them, and too 
consumed by their addiction to understand the real-life danger the typhoon presents beyond the bubble of the 'net. Given the 'Netheads' poverty and the implants' ability to eliminate physical sensations such as coldness and hunger, it is not difficult to understand the 'Netheads' desire to escape the physical world by losing themselves in the net. While Aurelio displayed little concern for the potential long-term effects of simming, the 'Netheads show little concern for their immediate situations. For them, the key to survival lies not in looking to the future, distant or otherwise, but in getting through the present. Like Pequé, the 'Netheads and Aurelio rely on escape, albeit a different form of escape, to survive. So, the 'Netheads suffer under Typhoon Dagundong, oblivious and close to death if not already dead, and the MaharlikaCo and its consolidated wealth, through Banco Maharlika, quite literally looms in the background, the survival of its members guaranteed.

Through stories such as "Dopplegänger", “e! True New Hollywoodland Stories: Paladin Jr.", and "Salbahe" (trans. "Naughty"), the reader also catches glimpses of the other megacorporations that rule the world — the ChimaeraCorp primarily responsible for creating clones, and the "Deutsche Telekom, BMW, SAP, Merck, Altana, Linde, and HVB, megacorps who had brought order to the chaos ridden [Europe]" (109). In this way, the reader sees that there is almost nothing left in the world that is not owned by, or at the very least connected to, these megacorporations.

But Hontiveros' political and economic commentary does not end with the MaharlikaCo and is also evident in his creation of the character Federico Rubio. In "The Twelfth Hour," is it established through a blog post that Rubio was once a popular Filipino actor who starred as a "nameless stranger who rode in on his white horse to face down the evil land barons and cattle rustlers, armed with nothing more than his steely-eyed squint and his pearl-handled revolver...[as] the railroaded police sergeant out for blood and righteous revenge... [as] the brave and noble Jungle Lord, Karzak, [and] the agimat-empowered costumed crime-fighter, Paladin" (20). After the release of his final film, Rubio became involved in politics. Later, he was elected as the president. He was eventually impeached and imprisoned for "Betrayal of Public Trust, Graft and Corruption, Bribery, and Culpable Violation of the Constitution" (20), though he was later pardoned. The blog post reads:

When he won the Presidency, critics and observers thought the masses (A) deluded themselves into thinking they were actually voting for the noble hero he once played onscreen, or (B) were hoping he could be the hero he played onscreen, that the man had the potential to be all that he had stood for. 
Everyone who believed the latter had effectively given Rubio a chance to put his money where his mouth was.

Sadly, they were all proven wrong. Rubio ended up putting their money into his pockets, while his mouth kept everyone oblivious by sprouting the most incredibly outrageous lies. (22)

The actor turned politician narrative is a familiar one in Philippine politics with Fernando Poe, Jr., Herbert Bautista, and Ramon “Bong” Revilla, Jr. as just a handful of names among the dozens who have parlayed their on-screen success into off-screen positions of political power (Uy). However, most similar to the fictional Federico Rubio is perhaps former president Joseph "Erap” Estrada. Erap Estrada was a popular film star during the 1960s-70s who was eventually elected as president of the Philippines in 1998 (“Looking Back”). In 2001, after corruption allegations and an impeachment trial, Estrada was ousted by People Power 2 and was later convicted of plunder (“Looking Back”).

Much like Rubio, Estrada was pardoned and remained popular with the masses. Eventually, Estrada returned to politics and became the mayor of Manila (Garrido 3 -4). The continued support for Estrada is due, in part, to his on-screen counterpart's image as the "defender of the oppressed" (Abinales and Amoroso qtd. in Garrido 8). "Estrada played the role of lower-class hero - squatter, jeepney driver, tenant farmer, rebel - so often and so memorably that movies featuring the actor in that role became an identifiable genre: 'Joseph Estrada proletarian potboilers' (Lacaba 1983)" (Garrido 8). By the time Estrada had run for office, the public was already accustomed to viewing him as a hero. As scholar Soledad S. Reyes writes:

Popular heroes [...] are excellent indices to the aspirations... of the millions who lead lives of desperation and continue to watch primetime shows on Channel 2 and Channel 7 for their temporary respite from pain. These millions are in need of saviors and authentic redeemers in actual life because they have encountered enough through their imagination. What exists in life does not correspond with the ideal, what is found in the imagination. But perhaps, individuals who play Christ-like figures in popular fiction could be depended on to provide hope to those who have little in life. (82)

The fictional hero turned hopeful real-life political hero returns to fiction in the form of Rubio, who does not re-enter politics as Estrada did but instead experiences a resurgence of popularity in the entertainment industry. In "The Twelfth Hour", the blog post explains that the latest trend in New Hollywoodland is to create remakes of films using clones of the original actors, clones that are designed not just to act as the character but to 
be the character. Rubio's clones are not Rubio per se but are instead the superhero Paladin or the Jungle Lord Karzak. The remakes of Rubio's movies are incredibly successful, and though there are still those who remember Rubio's failings as a president like the grandmother of the point-of-view character in “MRT, Then", his detractors seem to be in the minority. Later, as with most genetic sequences, the genetic templates for the Rubio clones were pirated to create Rubio dupes as well.

It is these dupes, or seroks now that they are in the Philippines, who serve as the collection's recurring characters. Upon learning of the seroks' existence, Rubio purchased and, in some cases, outright kidnapped his seroks to keep on his Hacienda, which is built with exact replicas of the film sets Rubio once worked on. Rubio forces his seroks to reenact the film scenes from his glory days and, in "The Twelfth Hour", has them shoot the critical blog poster for his comments in one of the reenactments.

“The Twelfth Hour" is told primarily from the point of view of one of Rubio's youngest seroks nicknamed Inchong, who was modeled after a character on the cusp of adulthood in one of Rubio's earlier films. Through conversations between the seroks, it is revealed that Rubio has managed to stay alive by undergoing numerous plastic surgery procedures, multiple organ transplants, gene therapy, and longevity treatments. Noneof the seroks know what Rubio looks like now, but they do know that he intends to use Inchong as a vessel to transfer his consciousness.

However, Inchong is saved by the familial nature of the bonds he shares with the other Rubio seroks, who view Inchong as a younger brother and seek to protect him. By highlighting the familial bonds betwee n the Rubio seroks - the most recurring characters in the collection - Hontiveros reinforces the reimagining of clones within the context of family, this time with a greater emphasis on existing relationships and loyalty, sensibilities that are also deeply embedded in Filipino culture (Cimafranca).

This loyalty leads to the seroks killing Rubio to save Inchong. After Rubio finally passes, the seroks marvel at the man who once was and who he turned into, saying that, in the end, he looked like "some kind of diseased dugong (trans. sea cow), or an engineered spork, those poor, twisted creatures New Hollywoodland genetix studios create for genre movies. He barely looked like a man" (Hontiveros 31). It is clear that it was Rubio's greed - greed for power, greed for control, greed for money, greed for life - that drove him to become the monster that he was, and though Rubio is dead, his genes are not as his clones and seroks live on. In a later story entitled "The Thirteenth Hour", it is revealed that Rubio's genes will also live on in the form of a child fathered by one of his seroks (a revelation that comes as a shock given that seroks are made to be sterile), which 
furthers the concept of seroks as a vehicle for family, but also brings in to existence another person who may be genetically predisposed to follow in Rubio's footsteps.

However, if there is one thing the collection makes evident through its recurring characters, it is that one's origins do not determine one's future. The eldest of the Rubio's seroks, Henry, says, “The second we came into being, we became our own discrete selves" (48). Just as Philippine science fiction borrows from the Anglophone mega-text and reimagines those tropes as carriers of alternate meaning, so do the seroks become their own persons, born of the same template but distinguished by the way they choose to imbue their lives with meaning. While Rubio chose to channel his prolonged life into "something base and cowardly and despicable" (31), his seroks and the child are not beholden to the same path.

In the case of the superhero Paladin seroks Roque, he chooses to become Paladin in the real world. In "Fiday" (trans. "Body Double/Bullet Catcher"), whose timeline overlaps with "The Twelfth Hour", the reader learns that Roque was initially employed as the stuntman for the original Paladin clone in the films through Roque's narration and a series of movie reviews. However, as the original clone's body gradually began to give out due to the harsh working conditions he was subjected to, Roque took on more and more scenes in the film, ultimately becoming the primary actor. Though Roque enjoyed being Paladin and the feeling of fulfilling his purpose, scripted as it may be, Roque was horrified at the treatment that the original clone faced and started planning his exit from New Hollywoodland. At the same time, Roque began to attract the attention of numerous studies in New Hollywoodland and was offered roles outside of the Paladin franchise. However, the Paladin producers, concerned over the Paladin image being associated with projects they did not approve of, decided to sell Roque to Rubio instead, thus tricking Roque into imprisonment at the Hacienda.

Meeting his fellow seroks only strengthened Roque's resolve. Roque says,

I was engineered to be a superhero, so I decided to be one.

I needed to help the others escape from the Hacienda, for one. And for two, there were a lot of people out there, not just dupes, who needed the kind of help someone like me could provide. You've seen the Paladin movies. You know what I mean. Just because they're movies, doesn't mean you can't find some truth in them.

Take a look outside your window and tell me the world doesn't need to be helped. (45) 
Roque eventually escapes the Hacienda and begins operating as a real-life Paladin. He saves a man from a beating in "Fiday", and though he is caught on camera, he does not step forward to claim credit for his actions. Later, he also returns to the Hacienda, and though he initially planned to kill Rubio for his crimes, in typical superhero fashion, Roque finds himself unable to take a life and instead manages to free Edgar, the seroks of the Jungle Lord Karzak. Later, in "Sapa”, Roque, as Paladin, can be seen rescuing the surviving 'Netheads and bringing them to a local shelter run by a barangay captain. There, the barangay captain warns him, "You'd better not turn out to be like [Rubio]", to which Roque answers, "He's not who I am" (116).

As the blog poster who was murdered for his anti-Rubio posts wrote, "this Paladin is the real deal [...] The guy's doing exactly what Paladin would do if he existed in real life" (44). It is later implied in the story "e! True New Hollywoodland Stories: Paladin Jr.", which takes the form of an interview, that the creator of the original Rubio clone templates, Dr. J. D. Peterson, is proud of Paladin's off-screen adventures, prouder still that the clone of Paladin Jr. has also taken off and joined up with Paladin. In Dr. Peterson's eyes, he engineered superheroes, and the seroks and the clone are doing exactly what superheroes are meant to do. However, due to the interview format of the story, what Dr. Peterson can explicitly say is restricted, and it is noted at the end of the story that some of what Dr. Peterson did say about Paladin and Paladin Jr. had been edited out of the interview's final cut.

"Salbahe" later confirms that Dr. Peterson knows far more than he let on in his interview. "Salbahe" focuses on the story of Gene, a wealthy socialite in love with the character of Karzak who tries and fails to acquire a Karzak clone from the film studio that owns the character. Gene later contacts Dr. Peterson directly and propositions him to steal the Karzak templates so that she can have a dupe of the clone made for herself. Dr. Peterson, who has been trying to figure out how to smuggle and produce dupes from the all the Rubio templates he created, is delighted at the prospect.

Gene then arranges for the stolen Rubio templates to be sent to Frederick Chan, the Overseer of the Hangzhou Collective, the Chinese company responsible for creating dupes. In "Haidào” (trans. Pirate), Chan reveals through a recording that he initially decided to produce the dup es as a homage to his Filipino mother, who was a fan of Rubio's work. Upon completing the duplication process, Chan says that creating the dupes became less about honoring his mother's love of Rubio's films and more about honoring his mother for who she was, honoring her "[belief] that she needed to leave the world a little bit better than it was when she had first come into it" (75). Chan saw the templates as an opportunity to "redress the cosmos for whatever ills [he] had so ignorantly 
cast before" (76). It was a "chance to restore balance [through] this invisible, intricate act that [he had] set in motion" (76). While the clones were created to be superheroes on-screen, their dupes or seroks were created to be superheroes off-screen, to be a source of good in real life just as they are on film. And so, the fictional hero played by Estrada turned hopeful real-life political hero returns to fiction in the form of Rubio, whose seroks succeeds in becoming the off-screen hero Rubio was not.

This is both an interesting and troubling turn of events. In the world of Seroks, the Paladin series is omnipresent, mentioned or referenced in 12 of the collection's 14 stories. Given Paladin's popularity, he is every bit the iconic hero, if not more, that the real-life masses have fallen for again and again. To still be relying on fictional characters to act as the savior, actualized though they might be within the context of the story, is a tricky plot point in terms of theme. However, this discussion has been limited to the first collection in the Seroks series, where the full implications of this plot point are yet to be fully revealed.

Regardless, in this dystopic vision of the Philippines, it cannot be denied that Paladin and Paladin Jr. serve as a much-needed force for good and source of hope. In one of the collection's last stories, "Crusade", Paladin and Paladin Jr. storm a chop shop, where hundreds of seroks have been killed and sold in pieces for organs buyers through the black market. The story is framed through the lens of a video camera where a masked Paladin speaks directly to an unknown audience, reminding the viewer that seroks are people "slaughtered by a system that's broken, that just doesn't care” (144) and that this, the world beyond the film screen, is the real crusade.

Ultimately, Seroks Iteration 1: Mirror Man is not a story about a particular character or group of characters but the story of the Philippines. Through its use of found footage, interviews, and other artifacts, Mirror Man builds its tension notby leaning on traditional sources of conflict such as man vs. society and man vs. man (though one could argue that Mirror Man sets up future instalments for such conflict) but by leaning on its world, by creating or recreating the history of this dystopic Philippines, and by using its point-of-view characters to observe different aspects of the current state of the world and society, and to explore what survival in such a world must entail.

Similar to other stories that deviate from using traditional sources of conflict, "almost nothing is happening if you think about it in terms of plot... [but] something about the quality of the landscape and what they were discovering [...] kept it interesting" (Hopkinson). In "stories like that, you are not going for a [rollercoaster] ride. You are visiting a place" (Lien). In the case of Mirror Man, Hontiveros goes beyond merely visiting a world and instead actively reconstructs it to make sense of the past, present, and future, and it is this act of sense -making 
through worldbuilding and rebuilding that drives the story forward. In doing so, Hontiveros is able to expose that the horror of Mirror Man's dystopia lies not in the extreme way technology has shaped the world, but in the Philippines' inability to escape its present. While one's origins do not determine one's future, the old adage that one must understand history to avoid repeating history holds true in Hontiveros' collection. Inspired by the political and economic milieu of the early 2000s, which has only worsened under President Rodrigo Duterte's regime, Hontiveros uses his world-driven dystopia to remind his reader to learn from history, "to look back over her shoulder to see what the past could possibly tell her" (Hontiveros 65), and to use those lessons to reconsider the trajectory of the Philippines and reimagine its future.

\section{Works Cited}

Abinales, Patricio. "Marcos and Mindanao: The Non-Moro Zones.” Rappler, Rappler, 25 Nov. 2016, www.rappler.com/voices/thought-leaders/marcos-mindanao-non-moro-zones.

Bertetti, Paolo. "Building Science-Fiction Worlds." World Building: Transmedia, Fans, Industries, edited by Marta Boni, Amsterdam University Press, 2017, pp.47-61.

Cimafranca, Dominique. "Why You Can't Write Filipino Science Fiction.” SlideShare, 26 May 2012, Www.slideshare.net/dominiquec/why-you-cant-write-filipino-science-fiction-

\section{4?fbclid=IwAR0nHGFAsY5c9JQ3nM1RBhPmKot381900cr2Y9rdqf9AQmqmyDN5ETdKs_0.}

Cruz, Vida (laviecestmoi). "Often, our protags are just trying to survive overwhelming odds. Survival is an active choice, you know. Survival is a story. Choosing to be strong in the face of the world ending, even if you can't blast a wall down to do it, is a choice. It's how we live these days.”27 Jan 2021, 7:03 PM. Tweet.

---. "Western editors, readers, and writers are too married to the three-act structure, to the type of storytelling that is driven by conflict, to that go-getter individualism. Please read more widely out of your comfort zone. A lot of great non-western stories do not hinge on these.” 27 Jan 2021, 7:05 PM. Tweet.

---. "Sometimes I wonder if you're all so hopped up on the conflict-driven story because that's exactly how your colonizer ancestors dealt with people different from them. Oops, I said it, sorry not sorry. Yes, even this mindset has roots in colonialism, deal with it." 27 Jan 2021, 7:07 PM. Tweet. 
Elemia, Camille. "FAST FACTS: How Marcos Silenced, Controlled the Media during Martial Law." Rappler, Rappler, 19 Sept. 2020, www.rappler.com/newsbreak/iq/how-marcos-silenced-media-press-freedommartial-law.

Garrido, Marco. "Why the Poor Support Populism: The Politics of Sincerity in Metro Manila.” American Journal of Sociology, vol. 123, no. 3, Nov. 2017,pp. 1-39., doi:10.1086/694076.

Gavilan, Jodesz. "Martial Law Victims, Kin: Still No Justice, Full Compensation after Decades.” Rappler, Rappler, 9 July 2019, www.rappler.com/nation/martial-law-victims-families-decry-lack-compensation.

Gerth, Jeff. “MARCOS'S WARTIME ROLE DISCREDITED IN U.S. FILES.” The New York Times, 23 Jan. 1986, www.nytimes.com/1986/01/23/world/marcos-s-wartime-role-discredited-in-us-files.html.

Hidalgo, Cristina Pantoja. "The Philippine Novel in English into the Twenty-First Century." World Literature Today, vol. 74, no. 2, 2000, pp. 333-336. JSTOR, www.jstor.org/stable/40155582. Accessed 26 Feb. 2021.

Hontiveros, David. Seroks Iteration 1: Mirror Man. Visprint, Inc., 2012.

Hopkinson, Nalo and Lien, Henry, panelists. “Beyond Three-Act Structure.” Nebula Conference Online, 6 Jun. 2021.

Jalkebro, Rikard. "Back to the Future? Martial Law and the Peace Processes in the Philippines." E-International Relations, E-International Relations, 4 Sept. 2017, www.e-ir.info/2017/09/04/back-to-the-future-martiallaw-and-the-peace-processes-in-the-

philippines/?fbclid=IwAR21h928Goh0HvweS5UYM8NWRz7OJVyYyKeb2REhlWqBH0Te1ly8Yw0eK -I.

Jurilla, Patricia May. “Conflicts and Contests: A History of the Filipino Novel in English.” Kritika Kultura, no. 27, Aug. 2016, pp. 3-20., doi:http://dx.doi.org/10.13185/KK2016.02702.

Kilian, Crawford. "Writing Science Fiction and Fantasy." The Handbook of Creative Writing, edited by Steven Earnshaw, Edinburgh University Press, 2007, pp. 134-145.

Lee, Gabriela. "Dreaming Domesticity: The Migrant Workforce in Philippine Science Fiction." SFRA Review, vol. 51, no. 1, Feb. 2021, pp. 133-140., http://sfrareview.files.wordpress.com/2021/02/sfra-review-51.1$\underline{\text { full-1.pdf }}$

“Looking Back at EDSA II: The Political Paths of Estrada and Arroyo.” Rappler, Rappler, 17 Jan. 2017, www.rappler.com/newsbreak/look-back-edsa-ii-joseph-estrada-gloria-arroyo.

Medina, Marielle. "What Went before: 1,838 Desaparecidossince Marcos.” INQUIRER.net, The Philippine Daily Inquirer, 18 Oct. 2012, newsinfo.inquirer.net/291050/what-went-before-1838-desaparecidos-since-marcos. 


\section{SARE, Vol. 58, Issue $1 \mid 2021$}

Novio, Eunice Barbara C. "What's in a Name?" Bangkok Post, Bangkok Post, 25 Feb. 2019, www.bangkokpost.com/business/1634674/whats-in-a-name-.

Punongbayan, JC. “[ANALYSIS] Just How Bad Was Corruption during the Marcos Years?” Rappler, Rappler, 19 Sept. 2019, www.rappler.com/voices/thought-leaders/analysis-just-how-bad-was-corruptionmarcosyears?fbclid=IwAR3DurT713_3DLeJzS7MuOJpgWI9JbNLt5e-VSvk1SAobn8_BLtT31D-VLE.

Ocampo, Victor Fernando R. "A Short and Incomplete History of Philippine ScienceFiction." The Infinite Library and Other Stories, Victor Fernando R. Ocampo, 5 May 2014, vrocampo.com/2014/05/05/a-short-andincomplete-history-of-philippine-science-

fiction/?fbclid=IwAR3qurNtE575pibt3GJ41DZwJ2g26FBhsZPvpQ1 YFWsvG2IkDX5kSSnKwAI.

Reyes, Soledad S. “Of Filipino Heroes Old and New.” From Darna to Zsazsa Zaturnnah: Desire and Fantasy: Essays on Literature and Popular Culture, Anvil Publishing, 2009, pp. 70-91.

Sands, Peter. "Utopias and Dystopias." Routledge Companion to Imaginary Worlds, edited by Mark J. P. Wolf, Routledge, 2018, pp. 177-183.

Tuttle, Lisa. Writing Fantasy and Science Fiction. A. \& C. Black, 2005.

Uy, Sasha Lim. "A Very Long List of Retired Actors Who Found New Beginnings as Politicians." Esquiremag.ph, Esquire Philippines, 11 Oct. 2017, www.esquiremag.ph/politics/news/retired-actors-whofound-new-beginnings-as-politicians-a00204-20171011-lfrm2.

VanderMeer, Jeff. Wonderbook: an Illustrated Guide to Creating Imaginative Fiction. Abrams Image, 2013.

Wolf, Mark J. P. "World Design.” Routledge Companion to Imaginary Worlds, edited by Mark J. P. Wolf, Routledge, 2018, pp.67-73.

Wright, Sean. "Book Review - Seroks (Iteration 1: Mirror Man) by David Hontiveros." Adventures of a Bookonaut, Apr. 2013, bookonaut.blogspot.com/2013/04/book-review-seroks-iteration-1-mirror.html. 